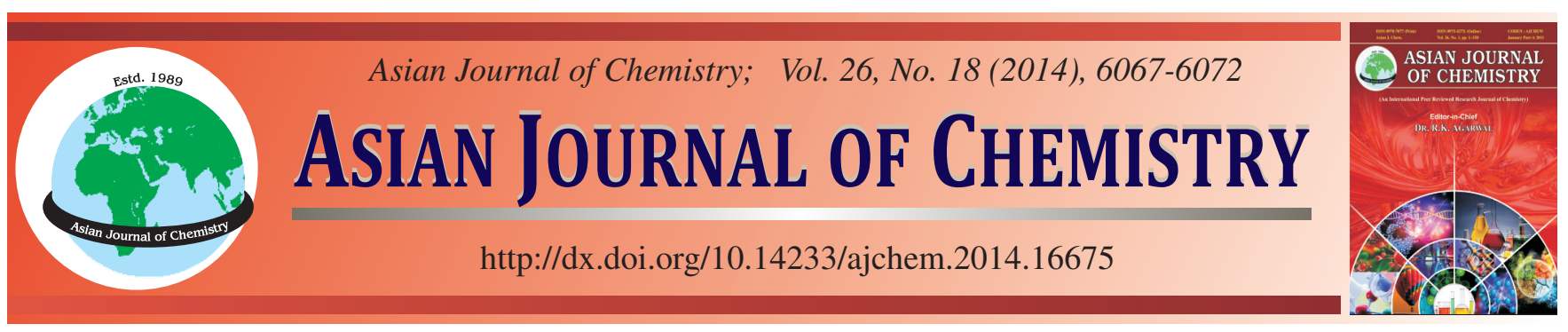

\title{
Seasonal Variation and Significance of Alkaline Phosphatase Activity on Algal Blooming in Chongqing Urban Section of Jialing River
}

Peng Pu, Zhi Zhang* and Min Wang

Key Laboratory of Three Gorges Reservoir Region's Eco-Environment, Chongqing University, Chongqing 400045, P.R. China

*Corresponding author: E-mail: zhangzhicq@126.com

Received: 12 November 2013;

Accepted: 15 January 2014;

Published online: 1 September 2014;

AJC-15855

Water samples were collected in a main branch of upstream Yangtze river, Jialing river, from 5 sampling sites along Chongqing to study
the significance of alkaline phosphatase activity to algal blooming in discharging stage of three Gorges reservoir. The seasonal evolution
of phosphorus fraction, alkaline phosphatase activity, algal cells amount and enzymatic kinetic parameters were investigated from 2011 to
2012 . Results showed the amount of algal cells was highest in discharging stages with low dissolved inorganic phosphorus and was lowest
in flood stages with high dissolved inorganic phosphorus. An expected negative correlation $\left(\mathrm{y}=0.0054 \mathrm{x}^{-1.6428}, \mathrm{R}^{2}=0.5153\right)$ between
alkaline phosphatase activity and dissolved inorganic phosphorus and positive correlation $\left(\mathrm{y}=0.0821 \mathrm{x}^{+0.3867}, \mathrm{R}^{2}=0.7266\right)$ between
alkaline phosphatase activity and algal cells amount were found. However a higher ratio of total nitrogen and total phosphorus indicated
phosphorus limitation during discharging stage. The co-occurring of high alkaline phosphatase activity and algal blooming can be explained
that alkaline phosphatase activity induces dissolved organic phosphorus decomposition and mineralization into dissolved inorganic
phosphorus, which is bio-available and supports algal growth when algal blooming occurs. The lower $\mathrm{K}_{\mathrm{m}}$ values and higher $\mathrm{V}_{\text {max }}$ values
during discharging stage indicated high substrate affinity and catalysis efficiency. The study covered a full operating period of three
Gorges reservoir, focusing on phosphorus fraction, kinetic parameters and their relationship with algal blooming, provided possible
explanations of the mechanism of algal blooming under phosphorus limiting conditions and highlighted the ecological significance of
alkaline phosphatase activity.

Keywords: Alkaline phosphatase activity, Extracellular enzyme, Eutrophication, Jialing river, Three Gorges Reservoir.

\section{INTRODUCTION}

Phosphorus which affects algal metabolism ${ }^{1}$ and primary production in aquatic environments, is considered as the main limiting nutrient in freshwater ecosystems ${ }^{2}$. Its concentration can be used to predict the biomass of phytoplankton ${ }^{3}$. Phosphorus is proved to be directly related to eutrophication and algal blooming ${ }^{4-6}$.

Natural waters contain particulate (PP) or dissolved ( $<0.45 \mathrm{~mm}$ ) form of phosphorus ${ }^{7}$. Dissolved total phosphorus (DTP) can is composed of dissolved inorganic phosphorus (DIP) and dissolved organic phosphorus (DOP). Among the various dissolved forms of phosphorus, phosphate is the most bio-available and readily usable for phytoplankton and bacteria $^{7}$. Dissolved organic phosphorus is one major form of dissolved total phosphorus pool in surface water and is one important phosphorus source when dissolved inorganic phosphorus is depleted. Dissolved inorganic phosphorus can be directly used by algae to support growth ${ }^{8-10}$, but its abundance is low in aquatic systems and often limits algal growth ${ }^{11,12}$. After depletion in the environment, dissolved inorganic phosphorus should be compensated. One important source is the decomposition and mineralization of dissolved organic phosphorus $^{13,14}$.

Alkaline phosphatases (APases) play a significantly important role in this process. Alkaline phosphatases are enzymes that hydrolyze different forms of organic phosphorus into orthophosphate because of their low specificity for organic moiety compared to more specific phosphatases ${ }^{15,16}$. When dissolved inorganic phosphorus concentration in the water column is low, algae may produce phosphatase that hydrolyzes organic phosphorus with the release of inorganic phosphate $e^{17,18}$. Microbial utilization of dissolved organic phosphorus through enzymatic hydrolysis is one major pathway in phosphorus cycle $^{19,20}$ and therefore, it is often used as an indicator of the phosphorus nutritional status of algae communities.

So far, great attention has been paid to alkaline phosphatases and its significance on microorganism to marine systems. A negative correlation between alkaline phosphatases and inorganic phosphorus is widely found in marine systems ${ }^{21-23}$. It can be explained that to cope with dissolved inorganic phosphorus depletion, marine algae will evolve a set of mechanisms 
to meet the phosphorus demand ${ }^{24}$. These mechanisms enable algae to utilize dissolved organic phosphorus, which is the major alternative phosphorus supply. However, few studies have investigated alkaline phosphatase activity and enzyme kinetic parameters as well as phosphorus status variation in fresh water system, which is usually used as water source for cities and is becoming indispensable because of freshwater eutrophication in many developing countries.

Three Gorges project on Yangtze river is the world's largest hydroelectric power project. Reservoir runs through Chongqing urban region and thus serves as main source of water supply for Chongqing and receives pollution loading. The three Gorges dam was preliminarily impounded in June $2003^{25}$. From 2010 to 2012, water level was elevated from 155 to 175 $\mathrm{m}$ causing a series of changes to hydraulic conditions (e.g., lower velocity), hydrology, sediments ${ }^{26}$ and aquatic ecosystems $^{27}$. From 2005 to 2008 in the Chongqing urban section of Jialing river, algae bloomed regularly during January to March each year and the dominant species Cyclotella asterocoststs proliferated rapidly and led to conspicuous peak of algae density ${ }^{28}$. Algal blooming which indicates water quality deterioration will pull down production of water-purifying plants because of the easily blocked filtration system and threaten public health because of algal toxin ${ }^{29}$.

In this study, we investigated phosphorus fraction, alkaline phosphatase activity variation, amount of algae cells and enzyme kinetic parameters from 5 sampling sites along Jialing river, aiming to explain the ecological significance of alkaline phosphatase activity variation on dissolved inorganic phosphorus concentration and algal blooming in fresh water systems.

\section{EXPERIMENTAL}

Three Gorges dam is impounded at early October every year until water level elevates to $175 \mathrm{~m}$ and discharges at early February next year. Therefore, October to February is known as the impounding stage, March to May is known as discharging stage. The period from May to July is flood stage, when water level lowers to $145 \mathrm{~m}$ (flood control level). The sampling sites were distributed along Jialing river, covering a distance of $17.6 \mathrm{~km}$ from Ciqikou to the junction of Jialing river and Yangtze river. All sampling sites were located at eutrophication-sensitive areas (Fig. 1).

Water was sampled by a polyvinyl chloride (PVC) sampler after well mixing water at $0.2 \mathrm{~m}$ and $3 \mathrm{~m}$ under the surface, $2 \mathrm{~m}$ from the river bank. At each sampling site, $100 \mathrm{~mL}$ of water was collected by sterilized glass bottles for analysis of enzyme- related index, while $500 \mathrm{~mL}$ of water was collected in polyvinyl chloride bottles. All samples were kept in coolboxes and analyzed within $24 \mathrm{~h}$.

Analytical method: Total nitrogen (TN) was measured using alkaline potassium persulfate digestion-ultraviolet spectrophotometry. Total phosphorus was measured by treating the sample at $450{ }^{\circ} \mathrm{C}$, followed by extraction by $\mathrm{HCl}$, while phosphate concentration was measured using the molybdenum blue method. Dissolved inorganic phosphorus was measured after filtration with $0.45-\mu \mathrm{m}$ membrane and extraction by $\mathrm{HCl}$ and the residual was treated at $450{ }^{\circ} \mathrm{C}$ to analyze organic

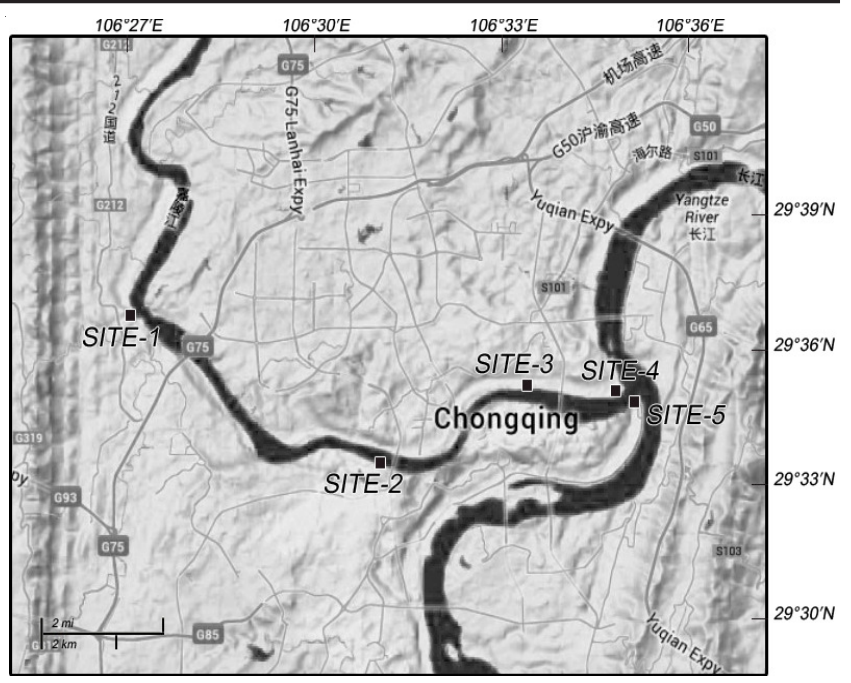

Fig. 1. Location of 5 sampling sites along Jialing river

phosphorus. Particulate phosphorus concentration was determined by the difference between dissolved total phosphorus and dissolved inorganic phosphorus (PP=DTP-DIP).

Alkaline phosphatase activity was determined spectrophotometrically as the release of $p$-nitrophenol from the model substrate $p$-nitrophenyl phosphate (pNPP). The reaction mixture for sediments contained: $5 \mathrm{~mL}$ of sample, $5 \mathrm{ml}$ of 0.3 mmol L ${ }^{-1} \mathrm{pNPP}$ and $1 \mathrm{~mL}$ of tris-buffer (pH 8.4). The mixture was incubated at $30^{\circ} \mathrm{C}$ for $6 \mathrm{~h}$. Reaction was terminated by addition of $0.1 \mathrm{~mol} \mathrm{~L}^{-1} \mathrm{NaOH}$. After addition of $1 \mathrm{~mL}$ of Gibbs solution, the mixture was diluted to $50 \mathrm{~mL}$. The samples were analyzed spectrophotometrically using Hach DR5000 spectrophotometer at $410 \mathrm{~nm}$. Each sample was conducted in triplicate.

The algal cells were counted and classified using a FuchsRosenthal counting chamber under a BA200 optical microscope (Motic Group Co., Ltd.) ${ }^{30}$. Each sample was conducted in triplicate until error was controlled within $10 \%$.

The Michaelis constant $\mathrm{K}_{\mathrm{m}}$ and the maximum enzyme velocity $\mathrm{V}_{\max }$ were computed by linear regression analysis of the Woolf-Augustinsson-Hofstee plots ${ }^{31}$.

\section{RESULTS AND DISCUSSION}

The seasonal variation in phosphorus fraction is presented in Fig. 2. It is noted that from February to April (discharging stages) of both 2011 and 2012, dissolved inorganic phosphorus decreased constantly, lowest dissolved inorganic phosphorus concentrations was found in April when discharging stage approached ending, dissolved organic phosphorus concentration declined with decreased dissolved inorganic phosphorus concentration. Particulate phosphorus concentration was low during impounding and discharging stage, this was mainly due to the low flow velocity, little precipitation and insufficient phosphorus supplement during the discharging stages, while the low flow velocity results in rapid algal propagation and huge phosphorus consumption. High particulate phosphorus concentration was found in July and August (flood stage) when the significant scouring effect in this region greatly increased particulate phosphorus content, while the abundant upstream inflow supplemented phosphorus. 


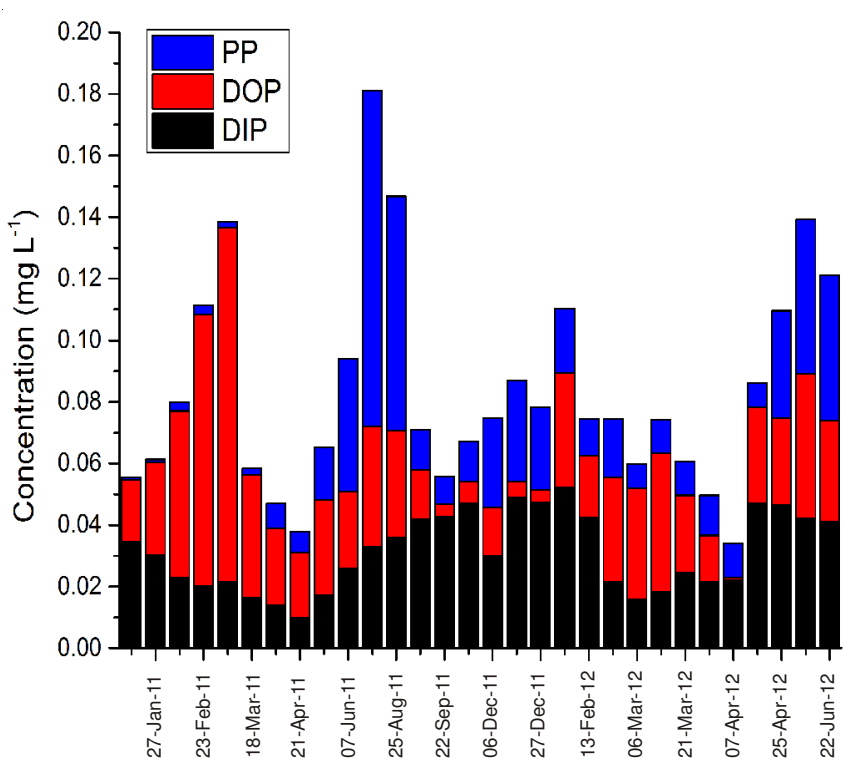

Fig. 2. Seasonal variation in phosphorus fraction at 5 sampling sites from 2011 to 2012

Algae growth was strongly related to alkaline phosphatase activity and phosphorus status transformation. The seasonal variations (2011-2012) of alkaline phosphatase activity dissolved inorganic phosphorus and algal cells amount are presented in Fig. 3a-b, respectively. There were 2 peaks of alkaline phosphatase activity during the study period 20112012, both of which took place in the end of March (discharging stage) each year and were significantly high in compare with that in other stages. Alkaline phosphatase activity was low and varied within a narrow range of $0.294-3.578 \mathrm{nmol} \mathrm{L}^{-1}$ $\min ^{-1}$ (mean of 5 sites). Dissolved inorganic phosphorus concentration decreased since the starting of January in both 2011 and 2012, was lowest when alkaline phosphatase activity was on peaks and increased after discharging stage. The most striking feature was the synchronous pattern of alkaline phosphatase activity and algal cells amount. Algal cells amount sharply increased with the alkaline phosphatase activity, peaking in discharging stage, the co-occurrence of algal blooming and alkaline phosphatase activity peaking was observed. In other stages, algal cells amount was lower and varied within a narrow range.

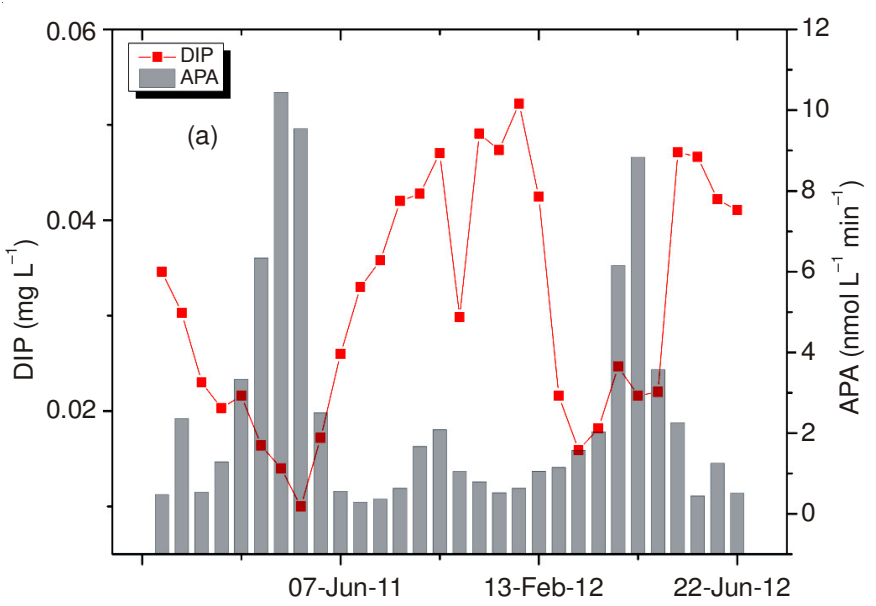

Seasonal variation in $\mathrm{V}_{\max }$ and $\mathrm{K}_{\mathrm{m}}$ values is presented in Fig. 4. $\mathrm{V}_{\max }$ values increased since February, peaking in March (discharging stage), in conjuction with low $\mathrm{K}_{\mathrm{m}}$ values. No significant difference was found in 5 sampling sites.

Phosphorus fractions and phosphorus limitation: The $\mathrm{N}: \mathrm{P}$ (TN:TP) ratio is a commonly used to indicate the nutrient status and algae growth of a water body. According to early whole-lake experimental research, high phosphorus concentration and low N:P supply ratio are favorable for the occurrence of cyanobacteria blooms ${ }^{32}$. Evaluation of the data from a wide range of temperate lakes and concluded that a N:P ratio of 29:1 will differentiate between lakes with cyanobacteria dominance (N:P $<29: 1$ by mass) and lakes without such dominance $(\mathrm{N}: \mathrm{P}>29: 1)$. A mass ratio of 22:1 is a more distinct boundary between lakes dominated by $\mathrm{N}$-fixing cyanobacteria and lakes with low density of these algae ${ }^{33}$. The DIN:DIP ratio has been frequently used to identify $\mathrm{N}$ - or P-limiting concentration in coastal waters ${ }^{34,35}$. Annual average DIN and dissolved inorganic phosphorus concentrations were measured to be 61.5 $\mathrm{M}$ and $1.03 \mathrm{M}$, respectively, in Masan Bay, Korea; hence, the DIN:DIP ratio was 59.7 and and the algal growth was considered to be P-limiting ${ }^{36}$. The dominant algae using dissolved inorganic phosphorus and DIN in Masan Bay were diatoms Skeletonema costatum, which is a representative marine diatom with a low half-saturation constant for dissolved inorganic phosphorus uptake $(0.48-0.68 \mu \mathrm{M})^{37}$.

In each year, TN:TP starts to rise before the discharging stage and peaks in late March, when the dissolved inorganic phosphorus content is minimized and phosphorus limitation is maximized; after that, TN:TP declines and minimizes between the two discharging stages; with the increase of upstream inflow, phosphorus is fully supplemented and phosphorus limitation is alleviated. The thresholds of phosphorus limitation are inconsistent among literatures, so there is no accurate NP ratio upon phosphorus limitation. Nevertheless, Fig. 5 shows that when algae boom around the discharging stage, NP ratio will necessarily increase, proving that algal booming occurs when phosphorus is relatively insufficient.

Correlation of dissolved inorganic phosphorus concentration, algal cell count and alkaline phosphatase activity: The data averaged from the 5 sampling sites were processed

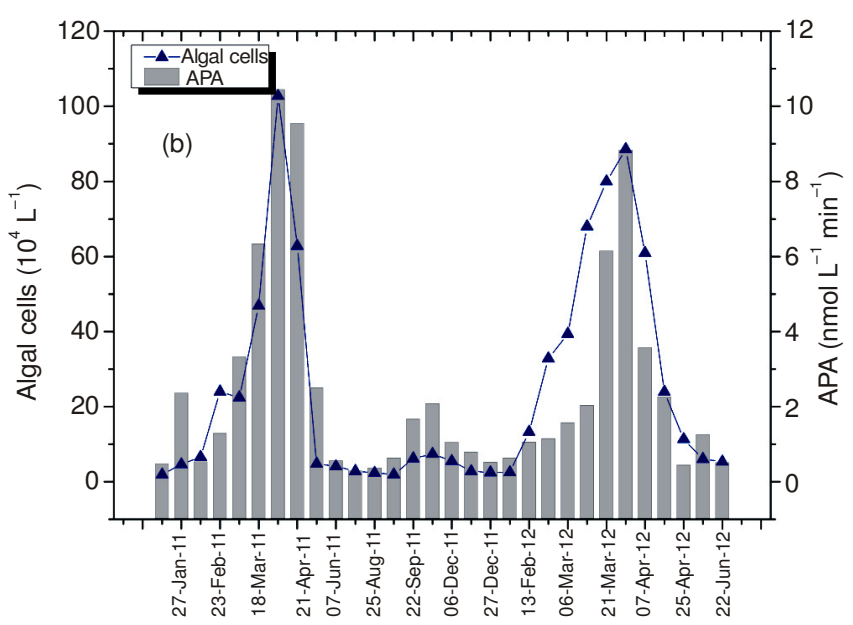

Fig. 3. (a) Seasonal variation in dissolved inorganic phosphorus concentration $v s$. alkaline phosphatase activity; (b) Seasonal variation in Algal cells amount $v s$. alkaline phosphatase activity 

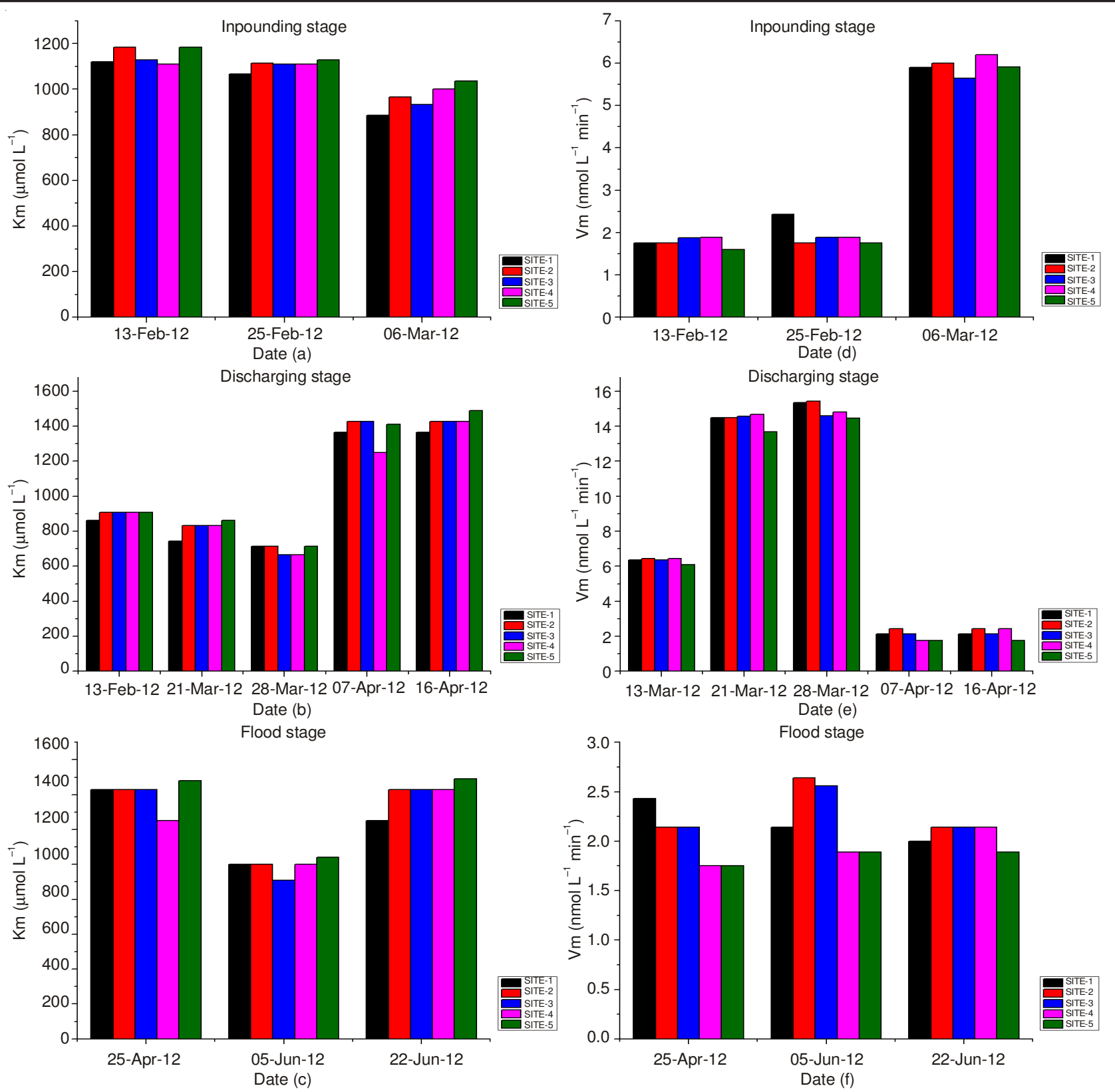

Fig. 4. Alkaline phosphatase kinetic parameters $K_{m}$ and $V_{\max }$ of 5 sampling sites in 3 stages

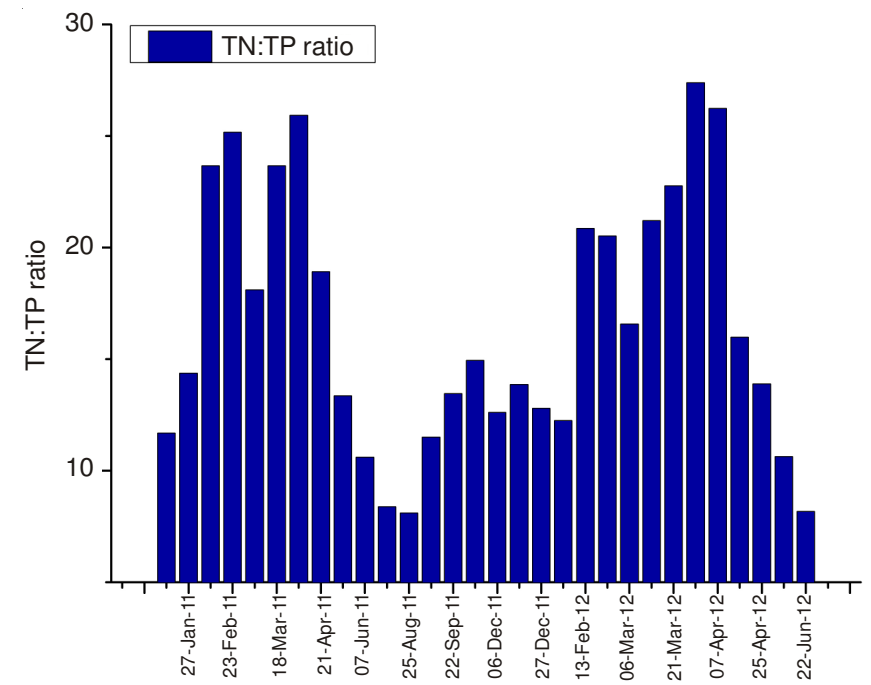

Fig. 5. Seasonal variation in TN:TP ratio from 2011 to 2012 on OriginLab 9. In previous studies in marine system, alkaline phosphatase activity was found to increase with the decrease of dissolved inorganic phosphorus ${ }^{38}$, thus a negative correlation was suggested $^{22}$. Suggested that the regulation of alkaline phosphatase by phosphate is described by an inverse hyperbolic relationship in a power fit regression of alkaline phosphatase activity on dissolved inorganic phosphorus concentration ${ }^{23}$, also suggested a near linear regression of dissolved inorganic phosphorus and total alkaline phosphatase activity. The results of our study in fresh water system agreed with previous researches. Dissolved inorganic phosphorus concentration and alkaline phosphatase activity were dissolved inorganic phosphorus concentration $(\mathrm{x})$ and alkaline phosphatase activity $(\mathrm{y})$ plots were best fitted by exponential regression $\left(\mathrm{y}=0.0054 \mathrm{x}^{-1.6428}\right.$, $\mathrm{R}^{2}=0.5153$ ), which indicated negative correlation (Fig. 6). Algal cell count $(\mathrm{x})$ and alkaline phosphatase activity $(\mathrm{y})$ plots were fitted by linear regression $\left(y=0.0821 x+0.3867, R^{2}=\right.$ 0.7266), which indicated positive correlation (Fig. 7). 
As temperature difference of about $10^{\circ} \mathrm{C}$ was noted, alkaline phosphatase activity would be expected to only double ${ }^{39}$. Therefore, temperature was considered as a less important factor and the increased alkaline phosphatase activity was the response of the algal communities to phosphorus limitation ${ }^{40}$. The negative correlation between alkaline phosphatase activity and dissolved inorganic phosphorus can be found in many other relevant studies. In the sediments of Mandovi Estuary, generally high phosphatase activity corresponded to low total phosphorus and low dissolved orthophosphate content (o-P), but high organic phosphorus content in the sediments ${ }^{41}$.

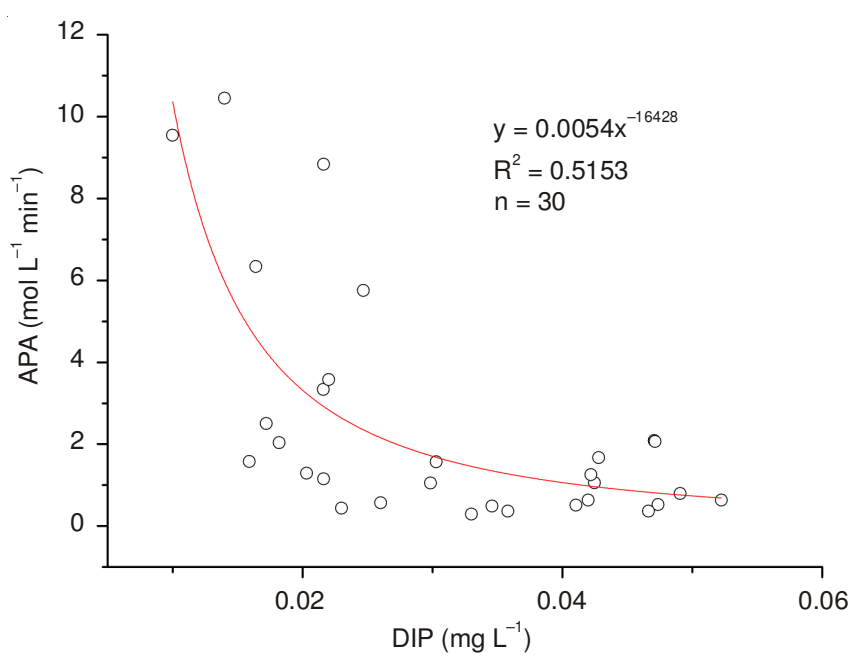

Fig. 6. Correlation between dissolved inorganic phosphorus concentration and alkaline phosphatase activity

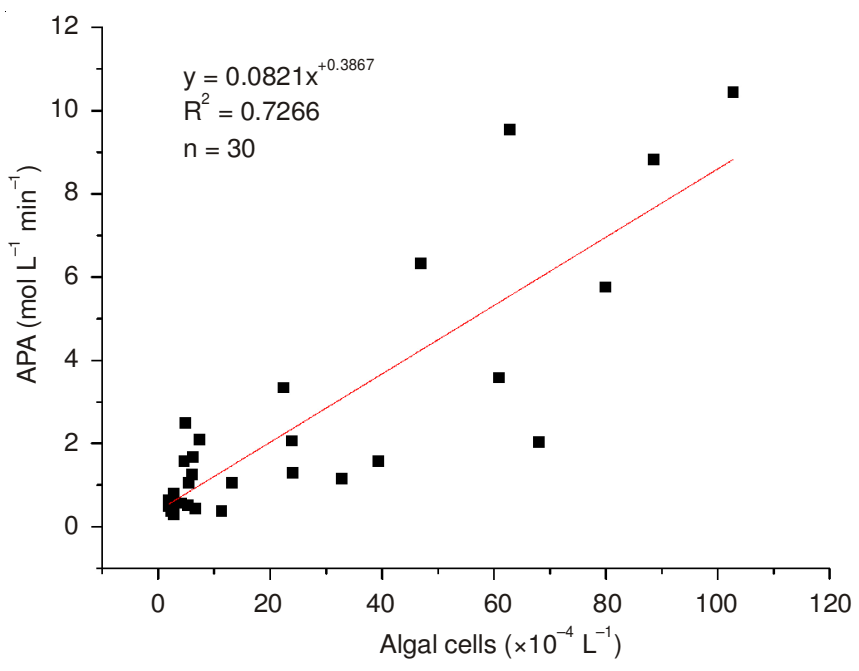

Fig. 7. Correlation between algal cell count and alkaline phosphatase activity

Alkaline phosphatase activity increased rapidly only when dissolved inorganic phosphorus concentration was low to a threshold, but this threshold is not a constant, as it varies with other factors ${ }^{42,43}$. During the study period 2011-2012, when dissolved inorganic phosphorus concentration was lower than $0.02 \mathrm{mgL}^{-1}$, alkaline phosphatase activity doubled rapidly; when dissolved inorganic phosphorus was higher than 0.02 $\mathrm{mg} \mathrm{L}^{-1}$, alkaline phosphatase activity decreased. In fact, alkaline phosphatase release is a very complicated process. Repressionderepression and end product inhibition of the enzymes are the proposed mechanisms underlying the relationship ${ }^{44}$.

Kinetic parameters $K_{m}$ and $V_{\text {max }}$ : The kinetic parameters $\mathrm{V}_{\max }$ (maximum activity) and Michaelis constant $\mathrm{K}_{\mathrm{m}}$ (Halfsaturation constant) for phosphatase in stream sediments were affected by the discharge rate, the water quality, the substrate (phosphomonoesters) and orthophosphate ${ }^{45}$. $\mathrm{V}_{\max }$ and $\mathrm{K}_{\mathrm{m}}$ were subjected to different environmental factors such as the $\mathrm{pH}$ and temperature of the substrate and varied with the origin of enzymes and the incubation conditions ${ }^{46}$.

$\mathrm{V}_{\max }$ and $\mathrm{K}_{\mathrm{m}}$ values were studied following a seasonal pattern, results showed $\mathrm{V}_{\max }$ and $\mathrm{K}_{\mathrm{m}}$ varied correspondingly with alkaline phosphatase activity. It was noted that high alkaline phosphatase activity were found in March and April (discharging stage) and algal cells amount reached plateau, on the other hand, lowest $K_{m}$ and highest $V_{\max }$ were also found in this stage. In other stages where alkaline phosphatase activity was low, high $\mathrm{K}_{\mathrm{m}}$ values and low $\mathrm{V}_{\max }$ values were found at all 5 sampling sites. The variation of kinetic parameters suggested that substrate affinity varied throughout the study period and alongwith alkaline phosphatase activity. However dissolved inorganic phosphorus concentration were low during discharging stage, it seemed that a higher ability of utilizing substrate to compensate phosphorus limitation mechanism were achieved, phosphorus uptake and regeneration efficiency were promoted, with higher substrate affinity and maximum reaction rate. Similar $\mathrm{K}_{\mathrm{m}}$ and $\mathrm{V}_{\max }$ ranges and variation pattern were also observed $^{22,47}$.

Algal blooming in Chongqing urban section on Jialing river from March to July each year is caused by Cyanophyta, Chlorophyta and Bacillariophyta, Cyclotella asterocoststs in particular $^{28}$, which broke out and dominated during 2005 to 2008, causing a great trouble to drinking water treatment plants in Chongqing. Laboratory experiments show that these species are capable of utilizing dissolved organic phosphorus for their growth and for supplementing dissolved inorganic phosphorus $^{38,48}$. Dissolved organic phosphorus utilization is important for the dominance of these algae in Chongqing urban section of Jialing river, where dissolved inorganic phosphorus is at limiting level for their growth.

\section{Conclusion}

In this study, the variations of phosphorus fractions, alkaline phosphatase activity and algal cell count from 5 sampling sites along Chongqing urban section in Jialing river were investigated between 2011 and 2012. The correlations of alkaline phosphatase activity with dissolved inorganic phosphorus and algal cell count were analyzed. The kinetic parameters $\mathrm{K}_{\mathrm{m}}$ and $\mathrm{V}_{\max }$ were also studied.

In the discharging stage, dissolved inorganic phosphorus concentration was lower than at other stages, but higher alkaline phosphatase activity and algal cell count were found. Strongly negative correlation was found between dissolved inorganic phosphorus and alkaline phosphatase activity whereas strongly positive correlation was found between algal cell count and alkaline phosphatase activity. Lower $\mathrm{K}_{\mathrm{m}}$ which indicated higher substrate affinity and higher $\mathrm{V}_{\max }$ which indicated higher 
reaction rate were also found as algal blooming broke out in the discharging stage.

Based on the results, it is argued that alkaline phosphatase activity was the driving force of dissolved inorganic phosphorus regeneration which strongly support algal biomass growth under dissolved inorganic phosphorus limiting environments in discharging stage, when 20-30 times of alkaline phosphatase activity occurred compared to other stages.

\section{ACKNOWLEDGEMENTS}

This work was supported by the National Natural Science Foundation of China "Extracellular Enzyme Function Mechanisms in Channel Reservoirs in Branch Junctions During Discharging Stages" (No. 51278510).

\section{REFERENCES}

1. A.D. Cembella, N.J. Antia and P.J. Harrison, Crit. Rev. Microbiol., 10, 317 (1982)

2. R. Wetzel, Limnology, WB Saunders Co., Philadelphia, Pennsylvania, USA, p. 743 (1975).

3. P. Dillon and F. Rigler, Limnol. Oceanogr., 19, 767 (1974).

4. J. Domagalski, C. Lin, Y. Luo, J. Kang, S. Wang, L.R. Brown and M.D. Munn, Agric. Water Manage., 94, 43 (2007).

5. J. Lehtoranta, P. Ekholm and H. Pitkänen, J. Mar. Syst., 74, 495 (2008).

6. Z.-H. Wang, Y. Liang and W. Kang, Harmful Algae, 12, 113 (2011).

7. C. Van Moorleghem, N. De Schutter, E. Smolders and R. Merckx, Water Res., 47, 3047 (2013).

8. I. Hernández, J. Fernández and F. Niell, J. Exp. Mar. Biol. Ecol., 173, 181 (1993).

9. I. Hernández, J. Pérez-Llorens, J. Fernández and F. Niell, Estuar. Coast. Shelf Sci., 39, 461 (1994).

10. H. Giraudet, J.-L. Berthon and B. Buisson, C. R. Acad. Sci. III, 320, 451 (1997).

11. C.R. Benitez-Nelson, Earth Sci. Rev., 51, 109 (2000)

12. S.L. Meseck, J.H. Alix, G.H. Wikfors and J. Evan Ward, Estuaries Coasts, 32, 1195 (2009).

13. Y.Y. Zhou and X.Y. Zhou, Water Res., 31, 1232 (1997).

14. F. Gambin, G. Bogé and D. Jamet, Mar. Environ. Res., 47, 441 (1999).

15. J.W. Ammerman and F. Azam, Science, 227, 1338 (1985).

16. X. Lin, H. Zhang, B. Huang and S. Lin, Harmful Algae, 17, 14 (2012).

17. E.J. Kuenzler and J.P. Perras, Biol. Bull., 128, 271 (1965).

18. W. Reichardt, Hydrobiologia, 38, 377 (1971).

19. M. Maeda and N. Taga, Mar. Biol., 20, 58 (1973).

20. M. Suzumura, K. Ishikawa and H. Ogawa, Limnol. Oceanogr., 43, 1553 (1998).
21. M. Sebastián, J. Arístegui, M.F. Montero, J. Escanez and F. Xavier Niell, Prog. Oceanogr., 62, 131 (2004).

22. C. Labry, D. Delmas and A. Herbland, J. Exp. Mar. Biol. Ecol., 318, 213 (2005).

23. H.K. Kwon, S.J. Oh and H.-S. Yang, Mar. Pollut. Bull., 62, 2476 (2011).

24. S.T. Dyhrman, J.W. Ammerman and B.A. Van Mooy, Microbes and the Marine Phosphorus Cycle (2007).

25. S. Kaichang, L. Kun and S. Zhiyu, Energy Procedia, 5, 377 (2011).

26. P. Liu, H. Chen, C. Deng, T. Mi, Q. Yao and Z. Yu, The Distribution and Variation Trend of Inorganic Nutrients in the Yangtze River Estuary and Adjacent Areas After the First Filling of the Three Gorges Dam, Periodical of Ocean University of China: S2 (2007).

27. Q.F. Zhang and Z.P. Lou, Environ. Sci. Policy, 14, 1132 (2011).

28. M. Wang, Z. Zhang, W. Guo, X. Zeng and S. Yuan, Res. Environ. Sci., 24 (2011).

29. L.E. Fleming, C. Rivero, J. Burns, C. Williams, J.A. Bean, K.A. Shea and J. Stinn, Harmful Algae, 1, 157 (2002).

30. H.M. Oh, C.Y. Ahn, J.W. Lee, T.S. Chon, K.H. Choi and Y.S. Park, Ecol. Modell., 203, 109 (2007).

31. S.Y. Seah, G. Labbé, S.R. Kaschabek, F. Reifenrath, W. Reineke and L.D. Eltis, J. Bacteriol., 183, 1511 (2001).

32. V.H. Smith, Science, 221, 669 (1983)

33. V.H. Smith, V. Bierman Jr., B. Jones and K. Havens, Arch. Hydrobiol. Suppl., 107, 71 (1995).

34. A.C. Redfield, Am. Sci., 46, 230A (1958).

35. A.C. Redfield, The Influence of Organisms on the Composition of Sea Water; The Sea, pp. 26-77 (1963).

36. C. Lee, Y. Kwon, K. Yang, P. Jang and S. Han, J. Korean Soc. Marine Environ. Eng., 1, 60 (1998)

37. K. Tarutani and T. Yamamoto, Phycolog. Res., 47, 27 (1997).

38. H. Yamaguchi, T. Nishijima, H. Nishitani, K. Fukami and M. Adachi, Nippon Suisan Gakkai Shi, 70, 123 (2004).

39. K. Pettersson and M. Jansson. Determination of Phosphatase Activity in Lake Water-A study of Methods; Proceedings: 20th Congress, Internationale Vereinigung fur Theoretische und Angewandte Limnologie (1978).

40. I. Ivancic, D. Fuks, T. Radic, D.M. Lyons, T. Šilovic, R. Kraus and R. Precali, Mar. Environ. Res., 69, 85 (2010).

41. C. DeSilva and N. Bhosle, Phosphorus Availability and Phosphatase Activity in the Sediments of Mandovi Estuary, Goa (1990).

42. R. Stevens and M.P. Parr, Freshw. Biol., 7, 351 (1977).

43. R.J. Chróst and J. Overbeck, Microb. Ecol., 13, 229 (1987).

44. R.J. Chróst, Environmental Control of the Synthesis and Activity of Aquatic Microbial Ectoenzymes, In: Microbial Enzymes in Aquatic Environments, Springer, pp. 29-59 (1991).

45. J. Marxsen and H.-H. Schmidt, Hydrobiologia, 253, 207 (1993).

46. D. Hui, M.A. Mayes and G. Wang, Soil Biol. Biochem., 65, 105 (2013).

47. Z. Yiyong, L. Jianqiu and Z. Min, Water Res., 36, 2084 (2002).

48. D.-I. Kim, T. Matsubara, S.J. Oh, Y. Shimasaki, Y. Oshima and T. Honjo, Nippon Suisan Gakkaishi, 73, 711 (2007). 